\title{
PERANAN ANTIOKSIDANT DALAM MENAIKKAN NAFSU MAKAN PASIEN TUMOR PANCREAS DISERTAI GIZI BURUK
}

\author{
Umrayani $^{1}$, Agussalim Bukhari ${ }^{2}$, Suryani As 'Ad ${ }^{3}$, Mardiana Madjid ${ }^{4}$ \\ ${ }^{1}$ PPDS Gizi Klinik Fakultas Kedokteran Universitas Hasanuddin Makassar \\ Email : umrayani2016@gmail.com \\ ${ }^{2}$ Departemen Gizi Klinik Fakultas Kedokteran Universitas Hasanuddin Makassar \\ Email : agussalimbukhari@yahoo.com \\ ${ }^{3}$ Departemen Gizi Klinik Fakultas Kedokteran Universitas Hasanuddin Makassar \\ Email:suryani_fkuh@yahoo.com \\ ${ }^{4}$ Departemen Gizi Klinik Fakultas Kedokteran Universitas Hasanuddin Makassar \\ Email : mardianamajid72@gmail.com
}

\begin{abstract}
Abstrak
\section{Latar Belakang}

Tumor pankreas merupakan jenis tumor yang dapat mengenai pankreas baik jaringan eksokrin maupun endokrin. Sebanyak 90\% merupakan tumor ganas jenis adenokarsinoma ductal pankreas yang merupakan neoplasma primer dimana frekuensinya $80 \%$ dari semua keganasan pankreas.
\end{abstract}

\section{Laporan kasus}

Seorang laki-laki umur 41 tahun dikonsul dari bagian bedah dengan diagnosis Post operasi laparatomi eksplorasi bypass biliodigestif choledocho-jejunostomy. Keluhan utama nafsu makan berkurang, Dialami sejak \pm 17 hari. Ada mual dan muntah tiap kali makan, nyeri perut dan nyeri luka operasi. Riwayat makan makanan berlemak tinggi ada, merokok ada, riwayat minum alkohol ada. Pemeriksaan fisis ditemukan konjungtiva anemis, sclera sub ikterik, thorax ada loss of subcutaneous fat, ekstremitas ada wasting dan edema dorsum pedis. Pasien didiagnosis dengan Severe Protein Energy Malnutrition ( 64\% Lila), status metabolic anemia normositik normokrom (9,4 g/dl), leukositosis (17600), hipoalbuminemia (2,3), hiponatremia (132), Hipocloremia (94).

Penatalaksanaan nutrisi dengan energi $1600 \mathrm{kkal}$, karbohidrat 55\%. Protein yang diberikan 1,5 g/kgBB/hari, lemak $24 \%$ melalui oral berupa makanan lunak, formula peptisol, buah, dan putih telur 2 butir perhari, diberikan kapsul ekstrak ikan gabus 2 kapsul/8 jam, zamel syrup 2 sendok/8 jam. Dan curcuma 400 mg/8jam.

\section{Kesimpulan}

Intervensi nutrisi yang optimal, monitoring serta edukasi gizi diperlukan untuk menunjang perbaikan kondisi klinis pasien kanker pankreas disertai dengan gizi buruk dan hipoalbuminemia.

Keywords: Nutrisi pada ca pancreas, Gizi buruk, hipoabuminemia

\section{Pendahuluan}

Tumor pankreas merupakan jenis tumor yang dapat mengenai pankreas baik jaringan eksokrin maupun endokrin. Kebanyakan untuk jenis tumor eksokrin pankreas berasal dari sel duktus dan sel asiner, 90\% merupakan tumor ganas jenis adenokarsinoma ductal pankreas yang merupakan neoplasma primer dimana 
frekuensinya $80 \%$ dari semua keganasan pankreas. ${ }^{1}$

Kegagalan terapi konvensional kanker pankreas dibuktikan dengan dengan angka harapan hidup 18\% dalam 1 tahun dan $4 \%$ dalam 5 tahun. Lebih dari $98 \%$ penderita kanker pankreas akan meninggal dunia dan sebagian besar pasien yang menderita kanker pankreas meninggal dalam enam bulan setelah diagnosis ditegakkan. Prognosis yang jelek ini karena ketidakmampuan mendiagnosis kanker pankreas pada stadium awal. Pankreas yang terletak jauh di dalam tubuh, sehingga tumor tidak dapat dilihat atau dirasakan oleh dokter selama pemeriksaan fisik rutin. Pasien biasanya tidak memiliki gejala sampai kanker telah menyebar ke organ lain. Keluhan dan gejala mulai timbul ketika kanker sudah dalam stadium lanjut dan metastasis ke nodus limfe regional dan organ-organ sekitar bahkan organ yang jauh ${ }^{2}$

Usia lanjut, merokok, genetik merupakan faktor risiko mayor kanker pankreas, sedangkan alkohol, diet tinggi lemak adalah faktor risiko minor. Risiko kanker pankreas 2,5-3,6 kali pada perokok dibanding bukan perokok. Obesitas, diabetes mellitus, pankreatitis kronik juga menjadi faktor risiko kanker pankreas. ${ }^{3}$
Gejala utama kanker pankreas adalah nyeri perut, ikterus dan penurunan berat badan. Gejala spesifik yang lain termasuk kembung, mual dan muntah, anoreksia dan asthenia. Pada pemeriksaan fisik ditemukan ikterus, temporal wasting, limfadenopati perifer, hepatomegaly dan ascites. Tes darah rutin umumnya tidak spesifik dan mungkin terdapat gangguan fungsi hati, hiperglikemia dan anemia. ${ }^{4}$

Penatalaksanaan karsinoma kaput pancreas umumnya dibagi menjadi 2, yaitu kuratif dan paliatif.. Kebanyakan tumor pankreas yang menyebabkan obstruksi traktus biliaris sudah inoperabel pada saat diagnosis ditegakkan yakni sekitar $80 \%$ kasus.

\section{Laporan Kasus}

Pasien laki-laki umur 41 tahun dikonsulkan ke bagian gizi klinis oleh TS. Bedah digestif untuk memperoleh penanganan gizi dengan diagnosis medis post operasi laparatomy eksplorasi + bypass biliodigestif + wound dehisiense Pada pasien ini telah terjadi penurunan berat badan yang progresifnya cepat, hal ini diakibatkan oleh proses keganasan, keluhan dari sistem gastrointestinal, malabsorpsi dan gangguan metabolisme. Sekitar 80-90\% kanker pankreas terjadi disfungsi eksokrin dan malabsorpsi yang berhubungan dengan kehilangan sekresi 
normal enzim pankreas akibat obstruksi duktus pankreas oleh tumor kaput pankreas atau akibat hilangnya fungsi parenkim pankreas oleh destruksi progresif dan perkembangan tumor. Malabsorpsi ini akhirnya akan mengakibatkan malnutrisi., 5,6 Keluhan gastrointestinal yang paling sering dirasakan adalah mual, rasa cepat penuh dan nyeri epigastrium. Keluhan itu dirasakan pasien sebelum pasien dilaksanakan operasi, Pada pemeriksaan fisis ditemukan anemia dan sub ikterus, pada thorax ditemukan loss of subcutaneous fat, abdomen pada eksttremitas ditemukan wasting dan edema dorsum pedis. Hal ini sesuai dengan gejala dan tanda kanker pankreas yaitu nyeri perut, ikterus dan penurunan berat badan. Sebagian besar (mencapai 90\%) pasien mengeluhkan nyeri epigastrium, menjalar ke belakang. Pada pasien ini diperoleh riwayat nyeri epigastrium yang hebat saat dirawat di RS. Wotu dan akhirnya dirujuk ke RSWS sebelum dirujuk ke RS. Wahidin Sudirohusodo. Penurunan berat badan yang cepat dan progres merupakan gejala yang paling sering muncul pada kanker pankreas, dan keadaan ini tidak berhubungan dengan lokasi atau tingkat keganasan. Ikterus merupakan gejala yang tampak pada sekitar $30 \%$ pasien, dan insidens meningkat sebagai progres dari penyakit. Ikterus lebih banyak ditemukan pada kanker kaput pankreas, namun obstruksi atau ikterus bisa juga merupakan akibat dari metastasis kanker ke hati atau nodus limfe di sekitar kandung empedu. Gejala seperti kandung empedu yang bisa teraba, massa di perut dan edema jarang dijumpai. $^{3}$

Pada pemeriksaan laboratorium tidak menunjukkan peningkatan profil lipid. Hal tersebut tidak sesuai dengan adanya diet tinggi lemak sebagai salah satu faktor risiko kanker pankreas. Faktor risiko yang ada pada pasien ini adalah merokok dan penggunaan pestisida, alcohol sebagai salah satu faktor resiko disangkal oleh keluarga pasien pada saat anamnesis awal

Saat dikonsul ditemukan sub-ikterus dengan peningkatan kadar bilirubin total dan bilirubin direk sebelum operasi dan setelah operasi choledojejunostomy kadar bilirubin menurun mendekati normal sampai pasien pulang. Hal ini menunjukkan bahwa ikterus yang menetap kemungkinan akibat dari metastasis kanker ke hati atau nodus limfe di sekitar kandung empedu.

Pada pemeriksaan fisis juga didapatkan adanya edema dorsum pedis serta pemeriksaan laboratorium menunjukkan penurunan kadar albumin. 
Sekitar 50\% pasien kanker pankreas dapat mengalami hepatomegali yang disebabkan oleh kolestasis sebagai sebab utama, hipertensi portal atau malignansi. Kenaikan dalam tekanan darah portal dan penurunan kadar albumin sebagai protein yang diangkut dalam darah mungkin bertanggung jawab dalam pembentukan gradient tekanan dan menyebabkan ascites dan edema pretibial dan dorsum pedis. Pada pasien ini diberikan infus albumin. Infus albumin diperlukan karena efektif mencegah penurunan volume intravaskuler. Selain itu, pemberian kapsul ikan gabus dengan dosis 3 x 2-3 kapsul untuk mengatasi hipoalbuminemia dan perbaikan keadaan umum pasien sebelum dan sesudah menjalani operasi. ${ }^{7,8}$

Kebutuhan kalori pada pasien ini berdasarkan perhitungan Harris-Benedict dengan faktor aktifitas 1,1 dan faktor stres 1,3 didapat kebutuhan energi total sebanyak 1600 kkal. jumlah karbohidrat yang diberikan sebanyak 55\%, tidak ada riwayat DM . Protein yang diberikan 1,5 $\mathrm{g} / \mathrm{kgBB} /$ hari dengan pertimbangan untuk memper-tahankan status gizi, mengatasi hipoalbuminemia dan mencegah penurunan berat badan yang sangat progresif akibat kanker pankreas. Sedangkan lemak hanya sekitar $24 \%$ (kolesterol <300mg, SFA <7\%, MUFA
$<15 \%$, PUFA $<10 \%$ ). Pada pasien kanker pankreas terjadi defisit kalori sebesar 300 $\mathrm{kkal} / \mathrm{hari}$. Defisit ini dikompensasi dengan memperbaiki asupan kalori dan protein yang disesuaikan dengan kebutuhan pasien. Beberapa penelitian terbaru merekomendasikan suplemen padat kalori dan protein yang lebih tinggi. Asupan protein pada pasien ini diperoleh dari nutrisi oral berupa makanan, ekstra putih telur dan suplementasi ekstrak ikan gabus yang kaya dengan albumin. ${ }^{8,9}$

Pemberian antioksidan pada pasien ini menjadi penting, antioksidan dapat meningkatkan respon kekebalan dengan jalan mengurangi beban radikal bebas. Antioksidan yang diberikan selain bersumber dari makanan, buah dan sayuran, juga dari suplementasi zink. Zink dibutuhkan untuk sintesis protein dan juga ko-faktor pada reaksi enzimatik. Zink merupakan komponen lebih dari 300 enzim yang berfungsi pada perbaikan luka, sintesis protein, kekebalan, dan proteksi terhadap radikal bebas. Zink juga dapat menghambat pertumbuhan bakteri. ${ }^{10}$

Curcumin adalah metabolit sekunder dari Curcuma longa L. Rhizoma yang memiliki efek antikanker yang signifikan, juga efek antimalarial, antioksidan, antiinflamasi. Curcumin juga telah diketahui berpengaruh dalam modulasi 
metabolism lemak sehingga bermanfaat pada obesitas. Curcumin synthase, suatu enzim yang terlibat dalam sintesis curcumin dikenal sebagai komponen antikanker yang poten. Efek curcumin terhadap regulasi siklus sel, apoptosis, faktor transkripsi NF- $\mathrm{B}$ and AP-1, autophagy, angiogenesis dan metastasis telah dibuktikan dengan jelas melalui berbagai penelitian. . Dhillon et.al tahun 2008 menunjukkan bahwa dosis curcumin pada kanker pancreas lanjut yaitu 8000 mg/hari selama 2 bulan. Pemberian curcuma pada pasien ini untuk menambah nafsu makan, memperbaiki fungsi hati dan sebagai anti kanker. ${ }^{11}$

Pemberian omega 3 juga direncanakan pada pasien ini. Penelitian yang dilakukan Barber MD, dkk tahun 1999 menunjukkan bahwa fish oil yang mengandung omega-3 memiliki efek anti kaheksia pada pasien dengan kanker pankreas.. Dosis asam lemak omega-3 yang dapat diberikan adalah EPA 2,2 gram/hari + DHA 0,96 gram. Menurut ASPEN tahun 2009, pemberian omega-3 pada kanker pankreas dengan dosis EPA 1,5-2,1 g/hari dan DHA 0,9-1 g/hari 12

Edukasi tentang terapi paliatif pada kanker diberikan secara terus menerus kepada pasien dan anggota keluarganya tentang pentingnya diet sesuai penyakitnya agar bisa mencapai kualitas hidup yang baik. Selama penanganan gizi, walaupun status gizi pasien mengalami penurunan sebelum operasi paliatif yaitu choledochojejunostomy, namun dengan penanganan nutrisi post operatif yang optimal, maka status gizi kembali normal yang ditandai dengan penambahan ukuran lingkar lengan atas. status metabolik mengalami perbaikan.

\section{Kesimpulan}

Kanker pankreas yang terdeteksi biasanya sudah sampai pada stadium lanjut, setelah penderita mengalami berbagai keluhan gastrointestinal dan gangguan metabolisme. .

Pemberian terapi paliatif dan dukungan nutrisi yang adekuat pada kanker pankreas stadium lanjut ditujukan untuk memperbaiki keadaan umum, mempertahankan status gizi dan memperbaiki kualitas hidup pasien serta meningkatkan angka harapan hidup.

Pemberian antioksidan pada pasien ini menjadi penting, antioksidan dapat meningkatkan respon kekebalan dengan jalan mengurangi beban radikal bebas. Antioksidan yang diberikan selain bersumber dari makanan, buah dan sayuran, juga dari suplementasi zink. Zink dibutuhkan untuk sintesis protein dan juga 
ko-faktor pada reaksi enzimatik. Zink merupakan komponen lebih dari 300 enzim yang berfungsi pada perbaikan luka, sintesis protein, kekebalan, dan proteksi terhadap radikal.

Curcumin synthase, suatu enzim yang terlibat dalam sintesis curcumin dikenal sebagai komponen antikanker yang poten. Pemberian curcuma pada pasien ini untuk menambah nafsu makan, memperbaiki fungsi hati dan sebagai anti kanker.

Edukasi tentang terapi paliatif pada kanker diberikan secara terus menerus kepada pasien dan anggota keluarganya tentang pentingnya diet sesuai penyakitnya agar bisa mencapai kualitas hidup yang baik.

\section{Daftar Pustaka}

1. Benson AI, Myerson, Robert J. (2011). Pancreatic, neuroendocrine GI mad Adrenal cancer. Diakses 8 januari 2017. Available from http//www.cancernetwork.com

2. Dragovic, Tomislav. (2012). Pancreatic Cancer. Diakses 1 januari 2016. Available from : http//www.emidicine.com

3. Thomson ABR. The Pancreas in First Principles of Gastroenterology. Fifth Edition. Janssen-Ortho. 2007.
4. Redlich et al. Tumors of the Pancreas, Gallbladder and Bile Ducts in Clinical Oncology. Third Edition 2003.

5. Damerla V, Gotlieb V, Larson H, Saif MW. Pancreatic Enzyme Supplementation in Pancreatic Cancer. $J$ Support Oncol. 2008;6:393-396.

6. Jimenez RE, Fernandez-del Castillo C. Tumors of the pancreas. In: Feldman M, Friedman LS, Brandt LJ, editor. Gastrointestinal and Liver Disease. 9th edition $\mathrm{p}$ 1017-30.

7. Schutte M, Hruban RH, Hedrick L. DPC4 gene in various tumor types. Cancer Res 1996;56:2527-32.

8. Generoso et al. Anorexia-Chahexia Syndrome in Pancreatic Cancer. JOP J Pancreas (Online) 2006; 7(2): 157-162.

9. American Cancer Society. Pancreatic Cancer. 2012. Available at: http://www.cancer. org/acs/groups/cid/documents/webcontent /003131-pdf.pdf

10. Hidalgo M. Pancreatic cancer. $N$ Eng $J$ Med. 2010; $362: 1605-17$

11. Spivak JL. Iron and the anemia of chronic disease. Oncology 2002;16:25-33.

12. Lohr JM, Heinemann V, Friess H (eds). Pancreatic Cancer. Bremen: Germany, Uni-Med, 2005. 
GRAFIK ASUPAN ENERGI

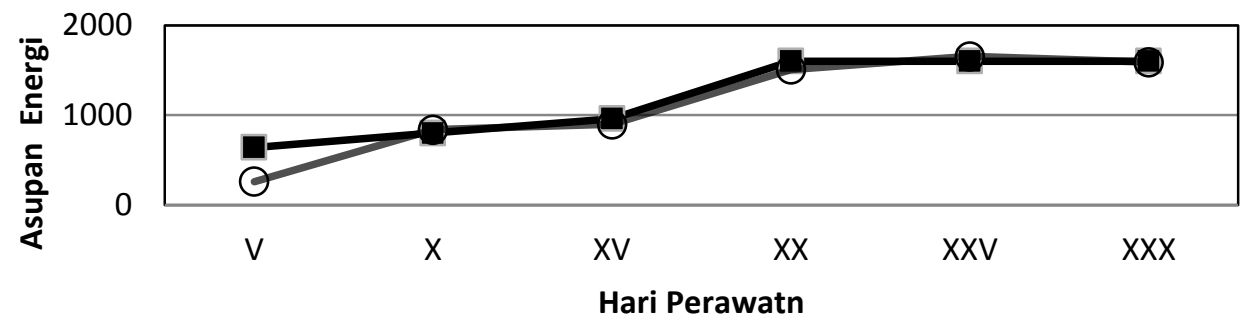

- - TARGET $O$ ASUPAN

\section{Grafik 1. Monitoring ASupan Energi Harian}

Dari grafik, memperlihatkan asupan kalori terjadi peningkatan pada hari perawatan ke-10, dan mencapai target kalori sampai pasien pulang

\section{Grafik Asupan Protein}

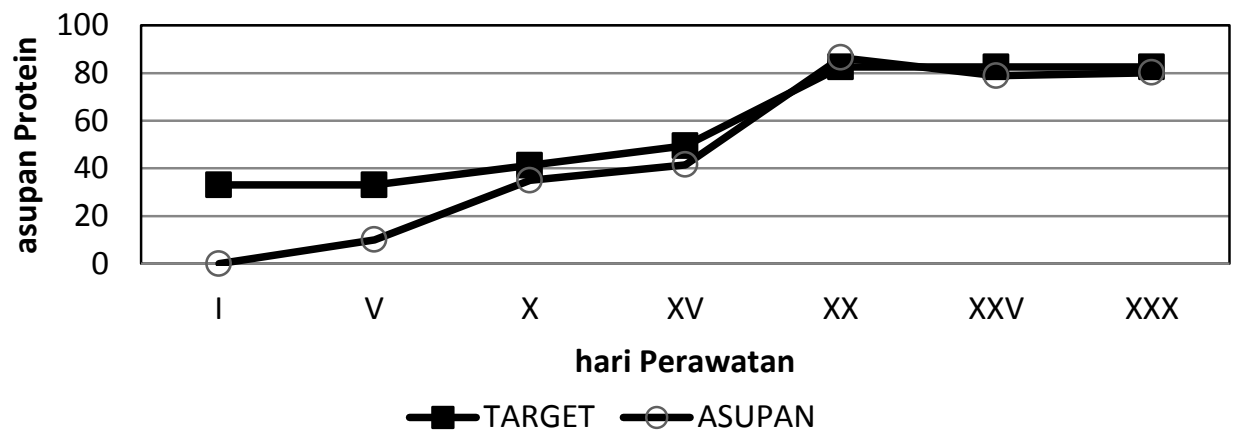

\section{Grafik 2. Monitoring Asupan Protein Harian}

Dari grafik, memperlihatkan asupan protein terjadi peningkatan pada hari perawatan ke-10, dan mencapai target protein sampai pasien pulang

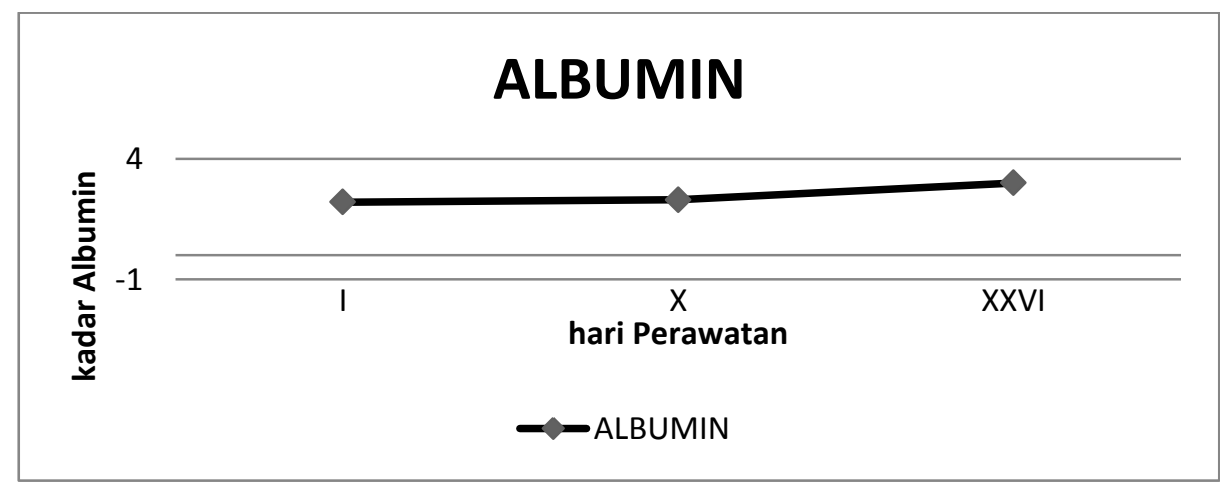

\section{Grafik 3. Monitoring Kadar Albumin}

Dari grafik, memperlihatkan peningkatan kadar albumin dengan pemberian human albumin di hari perawatan ke- 10 dan selanjutnya untuk koreksi hipoalbuminemia diberikan dengan asupan tinggi protein dan kapsul ekstrak ikan gabus. 